\title{
Formulasi sabun mandi cair dari daging putih buah semangka (Citrullus lanatus)
}

\author{
Nurul Arfiyanti Yusuf ${ }^{*}$, Nurul Sari Pandewa1, Vilia Payangan1, Diaz Permata ${ }^{1}$ \\ ${ }^{1}$ Farmasetika, Sekolah Tinggi Ilmu Farmasi Makassar, Makassar, Indonesia \\ DOI: https://doi.org/10.29303/sjp.v2i2.113
}

Article Info

Received : 2021-06-30

Revised : 2021-08-30

Accepted : 2021-09-24

\begin{abstract}
White flesh watermelon (Citrullus lanatus) is known to contain alkaloids, flavonoids, tannins and polyphenols. Research conducted by Rimando proves that watermelon rind contains the amino acid citrulline reaching $60 \%$ which is important in increasing levels of nitric oxide which is a regulator of blood flow, muscle energy metabolism, and mitochondrial respiration during exercise. This study aims to formulate bath soap from watermelon waste that meets the requirements with variations in the concentration of watermelon flesh extract $(3 \% ; 6 \% ; 9 \%)$. Watermelon flesh extract was extracted by maceration process using $70 \%$ ethanol. Evaluations were carried out in the form of organoleptic, $\mathrm{pH}$, free of alkali, high foam and density. The results showed that the three formulas were formulas that met the requirements according to SNI standards based on $\mathrm{pH}$ test, free alkali, foam height, and density.
\end{abstract}

Keywords: Watermelon (Citrullus lanatus), Formula, Bath Soap

Citation: $\quad$ Yusuf, N. A., Pandewa, N. S., Payangan, V., \& Permata, D. (2021). Formulasi sabun mandi cair dari daging putih buah semangka (Citrullus lanatus). Sasambo Journal of Pharmacy, 2(2), 55-59. https:// doi.org/10.29303/sjp.v2i2.113.

\section{Latar Belakang}

Tanaman semangka (Citrullus lanatus) merupakan salah satu tanaman penghasil buah yang banyak terdapat di Indonesia. Fungsinya tidak sekedar penghilang dahaga, tapi juga sebagai antioksidan yang baik (Sugiyanta, 2013). Semangka (Citrullus lanatus) termasuk dalam Cucurbitaceae keluarga yang mencakup mentimun, labu, dan labu. Catatan pertama budidayanya di Mediterania wilayah ini berasal dari sekitar 3.000 tahun yang lalu. Semangka adalah buah populer, yang biasanya langsung dikonsumsi segar. Selain itu, dapat diolah menjadi jus, selai, atau kulit acar, dan bijinya (dari kultivar biji) juga dikonsumsi (Abidin et al., 2016). Mayoritas masyarakat hanya mengkonsumsi bagian daging buah berwarna merah atau kuning yang segar, sedangkan kulit dan daging putih semangka hanya dibuang sebagai limbah tanpa ada pemanfaatan lebih lanjut (Niwanggalih et al., 2014)

Semangka (Citrullus vulgaris Schrad.) adalah sumber alami dan kaya asam amino sitrulin non- esensial. Sitrulin digunakan dalam sistem oksida nitrat pada manusia dan memiliki peran antioksidan dan vasodilatasi potensial. Kandungan sitrulin berkisar antara 3,9 hingga $28,5 \mathrm{mg} / \mathrm{g}$ berat kering dan serupa antara jenis berbiji dan tanpa biji (masing-masing 16,6 dan $20,3 \mathrm{mg} / \mathrm{g}$ berat kering). Semangka daging merah memiliki sitrulin sedikit lebih sedikit daripada semangka daging kuning atau oranye (masing-masing 7,4, 28,5 dan 14,2 mg/g berat kering) (Rimando \& Perkins-Veazie, 2005). Hasil skrining fitokimia menunjukkan bahwa ekstrak pulpa daging putih buah semangka mengandung senyawa alkaloid, flavonoid, tannin dan polifenol (Djala et al., 2016).

Asam amino sitrulin dalam semangka dapat dikonversi menjadi arginin dalam tubuh jika dikonsumsi dalam jumlah banyak (Niwanggalih et al., 2014). Konsumsi sitrulin dapat meningkatkan kadar arginin di dalam tubuh yang merupakan asam amino penting di dalam proses pembentukan nitrit oksida. Nitrit oksida yang terbentuk membantu meningkatkan aliran darah (vasodilatasi), metabolisme energi otot, dan 
respirasi mitokondria saat berolahraga. Sitrulin berperan dalam meningkatkan performa olahraga melalui jalur metabolisme baik aerobik maupun anaerobik (Rizal \& Segalita, 2018; Setiawan \& Widyastuti, 2016). Senyawa sitrulin dapat dimanfaatkan sebagai senyawa aktif dalam pembuatan sediaan sabun mandi untuk relaksasi otot.

Sabun merupakan pembersih yang dibuat dengan reaksi kimia antara kalium atau natrium dengan asam lemak dari minyak nabati atau lemak hewani. Sabun cair lebih diminati oleh masyarakat dibandingkan dengan sabun padat karena penggunaannya yang lebih praktis, lebih hemat, tidak terkontaminasi bakteri, mudah dibawa dan mudah disimpan (Agusta, 2016; Arfiansyah, 2015). Sabun mandi cair memiliki kelebihan antara lain proses pembuatannya relatif lebih mudah, biaya produksinya yang murah, serta mudah penyimpanan dan penggunaannya sehingga, sabun tidak mudah rusak (Dewan Standardisasi Nasional, 1996).

Penelitian ini memanfaatkan daging putih buah semangka yang mengandung sitrulin untuk dijadikan sabun mandi. Sediaan sabun tersebut diharapkan dapat menghilangkan kotoran yang melekat pada permukaan kulit, merangsang peredaran darah dan syaraf, serta mengembalikan kesegaran tubuh. Tujuan penelitian ini untuk memformulasi sabun mandi rileks dari daging putih buah semangka yang memenuhi persyaratan sesuai standar SNI (Dewan Standardisasi Nasional, 1996).

\section{Bahan dan Metode}

\section{Alat penelitian}

Alat yang digunakan adalah seperangkat alat maserasi, timbangan analitik (Mettler Toledo), rotary evaporator (Buchi), labu ukur (Duran), freeze dryer (MN12A), pH meter (Mettler Toledo), cawan petri, dan kaca objek.

\section{Bahan penelitian}

Bahan yang digunakan adalah allura red (Quadrant), aquadest (Sentana), asam stearat (Quadrant), cocamidopropyl, DMDM hydantoin (Quadrant), etanol $70 \%$ (Sentana), gliserin (Sentana), daging putih buah semangka (Makassar), natrium hidroksida (Quadrant), minyak zaitun (Sentana), parfum (Sentana), propilenglikol (Sentana), sodium laureth sulfat (Quadrant), tetrasodium EDTA (Sentana), trietanolamin (Sentana), dan virgin coconut oil (Sentana).

\section{Prosedur kerja}

Penyiapan sampel

Sampel daging putih buah semangka diperoleh dari Kota Makassar, Sulawesi Selatan.

\section{Ekstraksi daging putih buah semangka (Citrulus lanatus)}

Buah semangka dipotong dan dipisahkan antara daging buah dengan kulitnya, kemudian daging buahnya dicuci dengan air bersih. Daging putih buah semangka diolah menggunakan metode freeze drying. Filtrat daging putih buah semangka kemudian dibekukan pada freezer selama 24 jam pada suhu $-20^{\circ} \mathrm{C}$ dan diuapkan pada vakum.

\section{Formulasi sabun mandi cair daging putih buah semangka (Citrulus lanatus) \\ Tabel 1. Rancangan Formula Sabun Mandi Daging} Putih Buah Semangka (Citrullus lanatus)

\begin{tabular}{lccc}
\hline \multirow{2}{*}{ Bahan } & \multicolumn{3}{c}{ Konsentrasi (\%) } \\
\cline { 2 - 4 } & F1 & F2 & F3 \\
\hline Ekstrak daging putih buah & & & \\
semangka & 3 & 6 & 9 \\
(Citrulus lanatus) & & & \\
Natrium hidroksida (NaOH) & 10 & 10 & 10 \\
Minyak Zaitun & 5 & 5 & 5 \\
Virgin coconut oil & 5 & 5 & 5 \\
Gliserin & 5 & 5 & 5 \\
Asam stearat & 3 & 3 & 3 \\
Sodium laureth sulfat & 8 & 8 & 8 \\
Propilenglikol & 5 & 5 & 5 \\
Cocamidopropyl & 2 & 2 & 2 \\
Tetrasodium EDTA & 0,5 & 0,5 & 0,5 \\
Allura Red & 0,01 & 0,01 & 0,01 \\
DMDM Hydantoin & 0,3 & 0,3 & 0,3 \\
TEA & q.s & q.s & q.s \\
Parfum & q.s & q.s & q.s \\
Aquadest & ad 100 & ad 100 & ad 100 \\
\hline
\end{tabular}

Sabun mandi cair dari daging putih buah semangka dibuat dengan formula pada Tabel 1. Asam stearat dilebur dengan tambahan sodium laureth sulfat pada hot plate. $\mathrm{NaOH}$ dilarutkan dengan aquadest. Tetrasodium EDTA dilarutkan dan dicampurkan ke dalam campuran di atas. Semua sisa bahan ditambahkan (olive oil, propilenglikol, gliserin, VCO, cocamidopropyl dan pengawet DMDM hydantoin) kemudian diaduk homogen dan dicukupkan dengan aquadest. $\mathrm{pH}$ sediaan diukur dan ditambahkan TEA secukupnya lalu dihomogenkan.

\section{Evaluasi sediaan}

\section{Uji organoleptik}

Uji organoleptis bertujuan untuk menilai untuk melihat warna, aroma dan bentuk dari sabun mandi cair (Febrianti, 2013).

\section{2. $\mathrm{Uji} \mathrm{pH}$}

Pemeriksaan $\mathrm{pH}$ diawali dengan kalibrasi alat $\mathrm{pH}$ meter menggunakan larutan dapar $\mathrm{pH} 7$ dan $\mathrm{pH} 4$. Satu gram sediaan yang akan diperiksa diencerkan dengan 
air suling hingga $10 \mathrm{~mL}$. Sampel ditempatkan pada wadah kemudian dimasukkan $\mathrm{pH}$ meter, kemudian ditunggu hingga indikator $\mathrm{pH}$ meter stabil dan menunjukkan nilai $\mathrm{pH}$ yang konstan. Pemeriksaan $\mathrm{pH}$ dilakukan sebanyak tiga kali replikasi (Dewan Standardisasi Nasional, 1996).

\section{Uji alkali bebas}

Sebanyak $5 \mathrm{~g}$ sabun mandi cair ditimbang, dimasukkan ke dalam erlenmeyer $250 \mathrm{~mL}$. Ditambahkan $100 \mathrm{~mL}$ alkohol 96\% teknis dan beberapa tetes larutan indikator phenolptalein. Dipanaskan di atas penangas air memakai pendingin tegak selama 30 menit mendidih. Bila larutan berwarna merah, kemudian dititer dengan larutan $\mathrm{HCl} \quad 0.1 \mathrm{~N}$ dalam alkohol sampai warna merah tepat hilang (Dewan Standardisasi Nasional, 1996).

\section{Tinggi busa}

Sampel ditimbang sebanyak $1 \mathrm{~g}$, dimasukkan ke dalam tabung reaksi, kemudian ditambahkan aquadest ad $10 \mathrm{~mL}$, dikocok dengan membolak-balikkan tabung reaksi, lalu segera diukur tinggi busa yang dihasilkan dan diamkan 5 menit, kemudian diukur lagi tinggi busa yang dihasilkan setelah 5 menit (Dewan Standardisasi Nasional, 1996).

$$
\text { Uji Busa }=\frac{\text { Tinggi busa akhir }}{\text { Tinggi busa awal }} \times 100 \% \text {. }
$$

(Febrianti, 2013)

\section{Bobot jenis}

Penetapan bobot jenis menggunakan alat piknometer. Piknometer kosong ditimbang dan dicatat bobotnya. Kemudian piknometer diisi air dan ditimbang, lalu kedalam piknometer yang sama dimasukkan sampel sabun dan ditimbang. Rumus yang digunakan adalah:

$$
\text { Bobot jenis }=\frac{\text { Bobot sampel }}{\text { Bobot air }} \text {. }
$$

(Febrianti, 2013; Dewan Standardisasi Nasional, 1996)

\section{Hasil dan Pembahasan}

\section{Ekstrak}

Daging putih buah semangka yang diperoleh dari

Kota Makassar diolah menggunakan metode freeze drying, filtrat daging putih buah semangka yang telah dibekukan pada freezer selama 24 jam pada suhu $-20^{\circ} \mathrm{C}$ kemudian diuapkan pada vakum, agar filtrat yang membeku akan menguap ketika dipanaskan dan menghasilkan ekstrak yang kering. Ekstrak kering daging putih buah semangka dilihat pada gambar 1 .

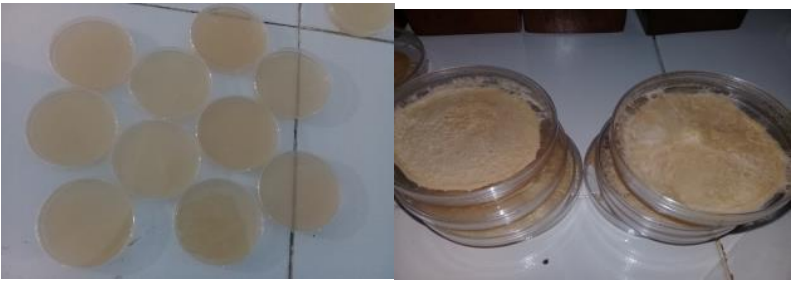

Gambar 1. Liofilisat daging putih buah semangka (Citrullus lanatus)

\section{Pengujian kualitatif}

Ekstrak daging putih buah semangka diuji terlebih dahulu dengan menggunakan uji kualitatif dimana pereaksi yang digunakan adalah pereaksi ninhydrin. Pereaksi ninhydrin merupakan hidrat dari triketon siklik, pereaksi yang digunakan untuk menguji adanya gugus asam amino. Pereaksi ninhydrin bila bereaksi dengan asam amino akan menghasilkan warna ungu. Hal ini karena ninhydrin merupakan suatu oksidator kuat yang dapat menyebabkan terjadinya dekarboksilasi oksidatif asam a-amino (Prastika et al., 2019).

\section{Evaluasi sediaan sabun cair \\ Uji organoleptik}

Sabun mandi cair ekstrak daging putih buah semangka dibuat 3 seri konsentrasi yaitu konsentrasi $3 \%$, 6\% dan 9\%. Evaluasi pertama yang dilakukan adalah uji organoleptik dimana tujuan dari evaluasi ini adalah untuk melihat warna, aroma dan bentuk dari sabun mandi cair. Sediaan sabun mandi cair ekstrak daging putih buah semangka dan hasil uji organoleptik dapat dilihat pada gambar 2 dan Tabel 2 .

Tabel 2. Hasil Pengamatan Organoleptis Sabun Mandi Daging Putih Buah Semangka (Citrullus lanatus)

\begin{tabular}{clrl}
\hline $\begin{array}{c}\text { Konsentrasi } \\
\text { ekstrak }\end{array}$ & Warna & Bentuk & \multicolumn{1}{c}{ Bau } \\
\hline $3 \%$ & Kuning & Agak cair & Bau khas \\
$6 \%$ & $\begin{array}{l}\text { Kuning } \\
\text { Keemasan }\end{array}$ & Agak cair & Bau khas \\
$9 \%$ & $\begin{array}{l}\text { Kuning } \\
\text { Kecoklatan }\end{array}$ & Kental & Bau khas \\
\hline
\end{tabular}

Gambar 2. Sediaan sabun mandi daging putih buah Uji pH semangka (Citrullus lanatus)

Berdasarkan tabel 3, pH sabun dengan konsentrasi ekstrak 3\% memiliki pH 8,97, konsentrasi 
$6 \%$ memiliki $\mathrm{pH}$ 8,80 dan konsentrasi 9\% memiliki $\mathrm{pH}$ 8,60. Maka berdasarkan hasil diketahui bahwa semakin besar konsentrasi ekstrak maka akan mempengaruhi $\mathrm{pH}$ sediaan sabun. pH sabun yang baik adalah 8-11 menurut standar nasional Indonesia (Dewan Standardisasi Nasional, 1996). pH sabun pada ketiga konsentrasi ekstrak memenuhi syarat $\mathrm{pH}$ sabun yang baik. Jika $\mathrm{pH}$ sediaan rendah atau asam maka akan menyebabkan iritasi pada kulit dan jika $\mathrm{pH}$ sediaan tinggi atau basa maka akan menyebabkan kulit kering ketika diaplikasikan (Subaidah et al., 2020).

Tabel 3. Hasil Pengukuran $\mathrm{pH}$

\begin{tabular}{ccc}
\hline \multirow{2}{*}{$\begin{array}{c}\text { Konsentrasi } \\
\text { ekstrak }\end{array}$} & \multicolumn{2}{c}{ pH sabun } \\
\cline { 2 - 3 } $3 \%$ & 8,97 & Setelah diencerkan \\
\hline $6 \%$ & 8,80 & 8,81 \\
$9 \%$ & 8,60 & 8,71 \\
\hline
\end{tabular}

\section{Uji tinggi busa}

Uji selanjutnya yang dilakukan adalah uji tinggi busa (Tabel 4). Tinggi busa yang terbentuk dari sabun mandi konsentrasi ekstrak 3\%, 6\%, dan 9\% berturutturut adalah 8,$5 ; 7,3$; dan $7 \mathrm{~cm}$. Setelah didiamkan selama 5 menit, tinggi busa yang diperoleh berturutturut sebesar 6,$5 ; 6,4 ;$ dan $5,5 \mathrm{~cm}$. Persentase tinggi busa sabun cair ekstrak daging putih buah semangka konsentrasi 3\%, 6\% dan 9\% berturut-turut sebesar $76,47 \%, 87,8 \%$ dan $88,57 \%$. Semakin tinggi konsentrasi daging putih buah semangka, maka persentase tinggi busa juga semakin meningkat. Semakin tinggi persentase tinggi busa, maka tingkat pembersihannya juga semakin lebih baik (Rahayu, 2015).

Tabel 4. Hasil Pengukuran Tinggi Busa

\begin{tabular}{ccc}
\hline \multirow{2}{*}{$\begin{array}{c}\text { Konsentrasi } \\
\text { ekstrak }\end{array}$} & \multicolumn{2}{c}{ Tinggi busa (cm) } \\
\cline { 2 - 3 } $3 \%$ & Awal & Akhir \\
$6 \%$ & 8,5 & 6,5 \\
$9 \%$ & 7,3 & 6,4 \\
\hline
\end{tabular}

\section{Uji alkali bebas}

Uji selanjutnya yang dikerjakan adalah uji alkali bebas dimana uji ini bertujuan untuk melihat alkali bebas di dalam sabun, dan melihat reaksi yang terjadi pada pembentukan sabun. Standar maksimum persen alkali bebas yang telah ditetapkan oleh SNI untuk sabun dengan basa $\mathrm{NaOH}$ tidak boleh melebihi 0,14\%. Berdasarkan hasil uji alkali bebas tidak terjadi perubahan warna maka diketahui bahwa alkali bebas sabun mandi cair ekstrak daging putih buah semangka memenuhi syarat SNI (Dewan Standardisasi Nasional, 1996).

\section{Uji bobot jenis}

Uji selanjutnya yang dilakukan adalah uji bobot jenis dimana tujuan dari uji ini yaitu untuk membandingkan bobot sabun mandi cair dan dengan air. Berdasarkan hasil uji, sabun mandi cair ekstrak 3\% memiliki bobot jenis sebesar $1,04 \mathrm{~g} / \mathrm{mL}$, ekstrak $6 \%$ sebesar 1,05 g/mL, dan ekstrak $9 \%$ sebesar 1,06 g/mL. Hasil ini sesuai dengan kriteria goals in range dalam rentang 1,01-1,1 g/mL, sehingga bobot jenis sabun yang dihasilkan sesuai dengan bobot jenis yang dipersyaratkan oleh SNI (Dewan Standardisasi Nasional, 1996).

\section{Kesimpulan}

Berdasarkan hasil penelitian dapat disimpulkan bahwa ketiga formula sabun mandi rileks dari daging putih buah semangka dengan variasi konsentrasi zat aktif memenuhi persyaratan SNI berdasarkan uji $\mathrm{pH}$, alkali bebas, tinggi busa, dan bobot jenis.

\section{Ucapan Terima Kasih}

Ucapan terima kasih kepada Direktorat Jenderal Pembelajaran dan Kemahasiswaan Kementerian Riset, Teknologi, dan Pendidikan Tinggi Republik Indonesia yang telah berperan sebagai pemberi dana.

\section{Daftar Pustaka}

Abidin, T., Agusnar, H., \& Dennis, D. (2016). Watermelon (Citrullus vulgaris): An Innovative Plant that accelerates the Healing of Pulpal Wound. World Journal of Dentistry, 7(3), 155-161. https://www.wjoud.com/doi/WJOUD/pdf/1 $\underline{0.5005 / \text { ip-journals-10015-1386 }}$

Agusta, W. T. (2015). Optimasi formula sabun cair antibakteri ekstrak etanol daun sirih merah (Piper crocatum Ruiz \& Pav) dengan variasi konsentrasi Virgin Coconut Oil (VCO) dan Kalium Hidroksida (KOH). Jurnal Mahasiswa Farmasi Fakultas Kedokteran UNTAN, 3(1), 1-14. https://www.neliti.com/id/publications/1891 92/optimasi-formula-sabun-cair-antibakteriekstrak-etanol-daun-sirih-merah-piper-cr\#cite

Arfiansyah, R. (2015). Token ekonomi dalam merubah kebersihan diri di Panti Asuahan Assidiqqi AsySyuhadaa Blimbing Malang. [Unpublished bachelor's thesis]. Universitas Islam Negeri Maulana Malik Ibrahim Malang. 
Dewan Standardisasi Nasional. (1996). Sabun Mandi Cair SNI 06-4085-1996. Departemen Perindustrian Nasional, Jakarta. http://lib.kemenperin.go.id/neo/detail.php?i $\mathrm{d}=226296$

Djala, F. L., Lyrawati, D., \& Soeharto, S. (2016). Ekstrak daging putih semangka (Citrulus vulgaris) menurunkan kolesterol total dan aktivitas Hidroksi-Metilglutaril-KoA Reduktase tikus hiperkolesterolemia. Jurnal Kedokteran Brawijaya, 29(2), 104-109. http://dx.doi.org/10.21776/ub.jkb.2016.029.02. $\underline{2}$

Febrianti, D. R. (2013). Formulasi sediaan sabun mandi cair minyak atsiri jeruk purut (Citrus hystrix DC.) dengan kokamidopropil betain sebagai surfaktan. [Unpublished bachelor's thesis]. Universitas Muhammadiyah Surakarta.

Niwanggalih, P., Waluyo, J., dan Asyiah, I. N. (2014). Pengaruh ekstrak kulit semangka (Citrullus lanatus (Thunb.)) terhadap jumlah neutrofil pada radang luka gores mencit (Mus musculus) jantan BALB/C dan pemanfaatannya sebagai karya ilmiah populer. Artikel Ilmiah Mahasiswa, 1(1), $1-4$. http://repository.unej.ac.id/handle/123456789 $\angle 63735$

Prastika, H. H., Ratnayani, K., Puspawati, N. M., \& Laksmiwati, A. A. I. A. M. (2019). Penggunaan enzim pepsin untuk produksi hidrolisat protein kacang gude (Cajanus cajan (L.) Millsp.) yang aktif antioksidan. Cakra Kimia, 7(2), 180-188. https://ojs.unud.ac.id/index.php/cakra/articl e/view/56199

Rahayu, S. (2015). Formulasi dan evaluasi mutu fisik sabun dari ekstrak rumput laut merah (Euchema cottoni). Jurnal Wiyata, 2(1), 14-18. https://www.iik.ac.id/v3/home/images/jour nal/lppm_jurnal_77_1418_SRI_RAHAYU.pdf.pdf

Rimando, M. A., \& Perkins-Veazie, M. P. (2005). Determination of citrulline in watermelon rind. Journal of Chromatography A, 1078(1-2), 196-200. https://pubmed.ncbi.nlm.nih.gov/16007998/

Rizal, M., \& Segalita, C. (2018). Peran asam amino sitrulin dalam meningkatkan performa olahraga pada atlet. Amerta Nutrition, 2(4), 299-306. http://dx.doi.org/10.20473/amnt.v2i4.2018.29 9-306

Setiawan, M. I, \& Widyastuti, N. (2016). Pengaruh pemberian jus semangka kuning (Citrulus lanatus) terhadap konsumsi oksigen maksimal $\left(\mathrm{VO}_{2} \max \right)$ pada atlet sepak bola. Journal of Nutrition College, 5(2), 64-70. https://doi.org/10.14710/jnc.v5i2.16361

Subaidah, W. A., Hajrin, W., \& Juliantoni, Y. (2020). Formulasi dan evaluasi sifat fisik lotion ekstrak etanol daun kemuning (Murraya paniculata (L) Jack) dan daun lidah buaya (Aloe vera Linn). Sasambo Journal of Pharmacy, 1(1), 12-16. https://jffk.unram.ac.id/index.php/sjp/article $\angle$ view $/ 6 / \mathrm{pdf}$

Sugiyanta, S., \& As'ari, H. (2013). Pengaruh pemberian ekstrak air kulit semangka (Citrullus vulgaris Schard) terhadap kadar glukosa tikus putih (Rattus norvegicus) yang diinduksi streptozotosin. Wahana: Tridarma Perguruan Tinggi, 60(1), 1-11. http://jurnal.unipasby.ac.id/index.php/whn/ article/view/1192 